\title{
PROTEIN BODY FORMATION IN THE DEVELOPING BARLEY ENDOSPERM
}

\author{
by \\ VERENA CAMERON-MILLS and DITER von WETTSTEIN \\ Department of Physiology, Carlsberg Laboratory \\ Gamle Carlsberg Vej 10, DK-2500 Copenhagen Valby
}

Keywords: Protein bodies, hordein, endosperm, high-lysine mutants

The ultrastructure of the pericarp, testa, aleurone and endosperm in a developing barley grain is presented in the form of a reconstructed section cut tangential to the dorsal surface of the grain and extending half way to the center of the endosperm.

Protein body formation in the endosperm is examined in Carlsberg II and Bomi barley and two mutants defective in hordein synthesis. Protein bodies of complex morphology are deposited in large as well as small vacuoles. They comprise clusters of homogeneous components, embedded in a fibrillar matrix, associated with electron-dense spheres and numerous vesicles. The fibrillar matrix is interpreted to be a transient stage in the condensation of storage proteins into a homogeneous structure. The polypeptide composition of protein bodies determines their ultrastructure. The reduction in the synthesis of ' $\mathrm{B}$ ' type hordein in mutant Risø 56 increases the proportion of the fibrillar matrix, while a more drastic alteration in storage protein condensation is observed in mutant Risø 1508, which is highly deficient in both ' $\mathrm{B}$ ' and ' $\mathrm{C}$ ' type hordein polypeptides.

\section{INTRODUCTION}

Due to their low content of essential amino acid, the majority of the storage proteins in the barley endosperm have a low nutritional value. Genetic improvement of the grain protein quality has been achieved by selecting high-lysine mutants $(25,31)$ but high-yielding commercial varieties have not so far been developed.
In some mutants this is due to a depression in starch synthesis $(23,25)$. A better understanding of the cellular, biochemical and molecular processes in storage protein as well as starch synthesis is required to permit genetic improvement of the nutritional quality of the barley grain without interfering with the yield. The high lysine content of some of the mutants results

Abbreviations: $\mathrm{a}=$ protein body component $\mathrm{a} ; \mathrm{b}=$ protein body component $\mathrm{b} ; \mathrm{c}=$ protein body component $\mathrm{c}$; SDS-PAGE = Sodium dodecylsulfate polyacrylamide gel electrophoresis. 
from a depressed synthesis of the lysine-poor hordein polypeptides $(23,25)$ while in Hiproly barley it is due to an increase in lysine-rich albumin and globulin polypeptides $(19,20,41)$. A considerable amount of information has now been gained regarding the biosynthesis of hordein and the composition of this heterogeneous group of at least 10 different polypeptides (8). Ultrastructural studies of protein body formation in the endosperm have supported the results of the biochemical studies but have only been published to a limited extent $(31,42)$.

In this paper the ultrastructural features of the immature barley endosperm and its surrounding tissues are presented with special emphasis on the early part of protein body deposition. The two high-lysine barley mutants Rise 56 (hor $2 \mathrm{ca}$ ) and Risø 1508 (lys 3a) have been compared with their respective wild types Carlsberg II and Bomi. Mutant Risø 56 is specifically depressed in the synthesis of the B hordein polypeptides owing to a mutation in the region of chromosome 5 containing their structural genes. The mutation Risø 1508 in chromosome 7 depresses the synthesis of both the $\mathrm{B}$ and $\mathrm{C}$ hordein polypeptides (25). The polypeptide composition of the protein bodies purified from these two mutants and their wild type has been identified (7). The changed polypeptide composition in the mutant protein bodies is reflected in an altered ultrastructure.

\section{MATERIALS AND METHODS}

\subsection{Plant material}

Barley plants (Hordeum vulgare L.) cv. Carlsberg II were grown in the field. Spikes were harvested 20 days after anthesis and the caryopses immediately prepared for transmission electron microscopy. Plants of Bomi, mutant Rise 1508 and mutant Rise 56 were grown in the phytotron at the Royal College of Forestry at Stockholm in continuous light and thermoperiods of $15^{\circ} \mathrm{C}$ for 16 hours and $10^{\circ} \mathrm{C}$ for 8 hours. Developing endosperms were fixed at various times after fertilization as determined by pollen dehiscence. The endosperms described in the present paper were taken as follows: Bomi, 20 days $(61 \mathrm{mg})$ and 28 days $(88 \mathrm{mg})$ after fertilization, mutant Risø 1508,24 days $(72 \mathrm{mg}$ ) and mutant Risø 56, 19 days (66 mg) after fertilization.

\subsection{Electron microscopy of developing grains}

Endosperms were freed from the lemma and palea and submerged in a solution of $2 \%$ or $6 \%$ glutaraldehyde in $60 \mathrm{~mm}$-phosphate buffer $\mathrm{pH}$ 7.3 and $1 \mathrm{~mm}$ slices were cut from the middle of the grain. The tissue slices were fixed in this solution for $20 \mathrm{~h}$ at $4{ }^{\circ} \mathrm{C}$ (Carlsberg II) or for $2 \mathrm{~h}$ at $20^{\circ} \mathrm{C}$, carefully washed in buffer and then postfixed in 1 to $2 \%$ osmium tetroxide in the same phosphate buffer for 2 to $4 \mathrm{~h}$ at room temperature. The slices were washed with distilled water, then stained with uranyl acetate, dehydrated, embedded, sectioned, contrasted and examined in the electron microscope as described previously (7).

\subsection{Polypeptide composition of barley endosperm protein bodies}

Protein bodies were isolated from endosperm tissue of the four barley lines examined and their polypeptide composition studied by SDS-PAGE as described previously (7).

\section{RESULTS AND DISCUSSION}

\subsection{Ultrastructure of the developing barley endosperm and its surrounding tissues}

Barley produces a dry, single seeded fruit or caryopsis comprising an embryo and endosperm, enclosed within a nucellar epidermis and seed coat (testa) which is in turn surrounded by the fruit coat (pericarp). The grain is an ovoid structure, rounded on the dorsal side and having a crease adjacent to the vascular strand on the ventral side. The morphology and ultrastructure of the endosperm and the surrounding seed and fruit coats, 20 days after anthesis, is presented in Figure 1 as a section taken tangential to the dorsal surface of a grain from Carlsberg II barley. The section was reconstructed from a series of 30 overlapping electron micrographs. At this stage of seed development cell division in the endosperm is completed, its water content has reached a maximum and the deposition of starch and storage protein has begun (23). It should be noted that the morphology of the 
pericarp tissues is not entirely uniform throughout the grain surface as has been comprehensively analysed by Cochrane and Duffus ( 10 .

\subsubsection{Fruit coat}

The fruit coat or pericarp (Figure 1), which derives from the ovary, is composed of several closely adhering cell layers namely an outer epidermis (epicarp), a hypodermis of 3 to 4 cells depth, and an inner pericarp of cross cells and then tube cells. The latter are not present at all places of the grain surface.

The outer pericarp comprises the epicarp and the hypodermis. The cells of the epicarp are elongated in the longitudinal axis of the grain and are three times as long as broad. There are no stomata on the dorsal surface, but the cells are covered with a water impervious cuticle (10). The cytoplasm contains scattered mitochondria and small plastids.

The hypodermis is a parenchyma of similarly elongated cells whose thickened walls lack a cuticle and are oblique at the ends. The cells are vacuole filled and contain numerous mitochondria, proplastids and Golgi apparatuses. As the endosperm expands during grain filling the cells are stretched and degenerate into a layer of crushed cell walls.

The inner pericarp in Figure 1, consists of two layers of elongated, chlorenchymatous cross cells lying at right angles to the long axis of the grain, surrounded by large intercellular spaces. The pericarp derives its green colour and photosynthesizing capacity from these chloroplast-containing cross cells. The photosynthetic activity of this tissue is at a maximum at this stage of development (13), as evidenced by the starchfilled chloroplasts with well developed grana seen in the section. Carbon dioxide fixation in the pericarp employs the $\mathrm{C}_{4}$ pathway and it is thought that respired $\mathrm{CO}_{2}$ from the metabolically active endosperm is assimilated rather than atmospheric $\mathrm{CO}_{2}(33)$.

The inner epidermis of the ovary, comprised of the tube cells, is greatly stretched during grain development and the cells are widely dispersed on the dorsal surface (10). Tube cells, which are absent from this section, lie parallel to the long axis of the grain.

\subsubsection{Seed coat}

The seed coat or testa comprises two cell layers which derive from the two integuments of the ovule. Cells of the outer layer are smaller and the two layers are bounded by thick cell walls and a cuticle on the inner and outer surfaces. The cytoplasm of the cells is in the process of degenerating and known to be filled with a lipid containing material (3).

The nucellus, forming the inner layer of the testa, has elongated and vacuolate cells, which adhere closely to the endosperm and have greatly thickened outer walls. The vacuoles contain deposits of unknown composition.

\subsubsection{Endosperm}

The outer three cell layers of the endosperm are differentiated to form the aleurone. The aleurone tissue plays an essential part during germination in the mobilization of starch and protein reserves stored in the endosperm. The cells are roughly cuboid in shape, with large nuclei, and the cytoplasm is densely packed with endoplasmic reticulum and organelles. Numerous mitochondria, aleurone grains and oleosomes can be discerned in the mature seed although starch grains are absent from this tissue (42).

The oleosomes are lipid bodies which lie in the cytoplasm, without a delimiting membrane, tightly packed around the aleurone grains. They are primarily deposits of triglyceride and a small amount of phospholipid and protein (17). Hydrolysis of these lipid reserves by lipases from the aleurone grains, is probably an important source of fatty acids during germination.

Employing a variety of fixation and staining techniques, the mature barley aleurone grain has been shown to comprise a protein-filled body surrounded by a unit membrane, containing two inclusions, globoids and crystalloids $(16,21,24)$. Globoids are composed of phytin, the $\mathrm{Ca}^{++}$ $\mathrm{Mg}^{++}$salt of myoinositol hexaphosphate. There are between one and three globoids per grain and they increase in size from $0.5 \mu$ to $3.0 \mu$ towards the inner aleurone cell layer. The crystalloids ( $1-$ $1.5 \mu$ in diameter) appear to be composed of densely packed proteins and polysaccharides (16).

At 20 days after fertilization the aleurone grains are not developed (Figure 1) but the 
numerous vacuoles which will be converted into aleurone grains are present. The initial precipitation of material in these vacuoles has taken place in the form of irregular deposits of moderate electron density and very dense globules. The inset of Figure 1 contains an advanced stage of aleurone grain formation from a 28 day old seed showing the dense deposit with a transparent central core and peripheral matrix inside the vacuole, very similar to the developing maize aleurone grain (24).

Oleosome formation in the cytoplasm is in full progress at 20 days after fertilization (Figure 1). Large numbers of mitochondria and proplastids with tiny starch grains are characteristic of the developing aleurone cell.

During differentiation of the endosperm, the cells of the sub-aleurone are the last to be formed and are the smallest. Several rows of radially elongated, prismatic cells extent inwards from the sub-aleurone layer to the central, irregularshaped cells. The section in Figure 1 extends through the sub-aleurone and three layers of prismatic cells. The endosperm tissue can be distinguished from the aleurone by the absence of aleurone grains and the appearance of large cell vacuoles and numerous starch-filled amyloplasts. The amyloplast envelope and the narrow layer of stroma between the envelope and the starch grain is easily disturbed by the fixation process. Starch deposition begins at the apex of the grain and around the crease. While the youngest cells in the sub-aleurone layer are the last to accumulate starch, they contain the greatest concentration of storage protein bodies at maturity (4). Oleosomes are seen in the cytoplasm throughout the endosperm although not nearly as numerous as in the aleurone. Although there is evidence of considerable starch biosynthesis in the 20 day endosperm and the mitochondria are numerous, storage protein synthesis has only just begun. Proliferation of the rough endoplasmic reticulum, which is a major site of storage protein synthesis, is only seen in a few cells.

At this early stage of development, protein bodies make their appearance in both large and small vacuoles of the endosperm cells. In most cases the protein bodies are seen as individual homogeneous deposits surrounded by small, irregular deposits of electron-dense material.
Where storage protein is deposited in small vacuoles, the homogeneous bodies are clustered together and the spaces between them are often filled with fibrillar material. The presence of this fibrillar matrix is a feature of sites of prolific storage protein deposition in small vacuoles, commonly found at the periphery of the cells. Two such sites are seen in an endosperm cell

Abbreviations to figures: $a=$ protein body component $\mathrm{a} ; \mathrm{ag}=$ aleurone grain $; \mathrm{b}=$ protein body component $\mathbf{b}$; $\mathrm{c}=$ protein body component $\mathrm{c} ; \mathrm{ch}=$ chloroplast; $\mathrm{cu}=$ cuticle; $\mathrm{cw}=$ cell wall $; \mathrm{g}=$ Golgi apparatus $\mathrm{m}=$ mitochondrion; $\mathrm{n}=$ nucleus; $\mathrm{o}=$ oleosome $\mathrm{pb}=$ protein body; rer $=$ rough endoplasmic reticulum; $\mathrm{s}=$ starch $; \mathrm{v}=$ vacuole $; \mathrm{ve}=$ vesicle $; \mathrm{vm}=\mathrm{vacu}$ olar membrane.

Figure 2. Protein bodies, comprising components a, $\mathrm{b}$ and $\mathrm{c}$, in prismatic endosperm cells of Carlsberg II barley 20 days after anthesis. Magnification: $\times 6,000$.

Figure 3. Protein bodies from Carlsberg II barley are seen as clusters of homogeneous deposits (a) embedded in a fibrillar matrix (b) within small vacuoles (A and B) and as individual homogeneous deposits dispersed through a large vacuole (C). Magnification: $\mathrm{A}, \mathrm{B}=\times 30,000 ; \mathrm{C}=15,000$.

Figure 4. Protein bodies in the developing endosperm of Bomi barley at 20 days (A) and 28 days (B) after anthesis. Magnification: $A=\times 15,000 ; B=$ $\times 30,000$.

Figure 5. Protein bodies containing homogeneous deposits (a), electron dense spheres (c) and vesicles (ve) embedded in large amounts of fibrillar matrix (b) found in developing endosperm of mutant Risø 56 at 19 days after anthesis. Magnification: $A=\times 9,000$; B, $\mathrm{C}=\times 30,000 ; \mathrm{D}=\times 60,000$.

Figure 6. The protein bodies of mutant Risø 1508 at 24 days after anthesis consist primarily of the fibrillar matrix (b) together with several electrondense spheres (c) and vesicles (ve). Magnification: $\mathrm{A}=\times 15,000 ; \mathrm{B}=\times 30,000$.

Figure 7. Comparative polypeptide composition of protein bodies purified from wild type and mutant barley endosperm and analysed by SDS-PAGE (7). Arrows indicate major non-hordein polypeptides specific to protein bodies. 


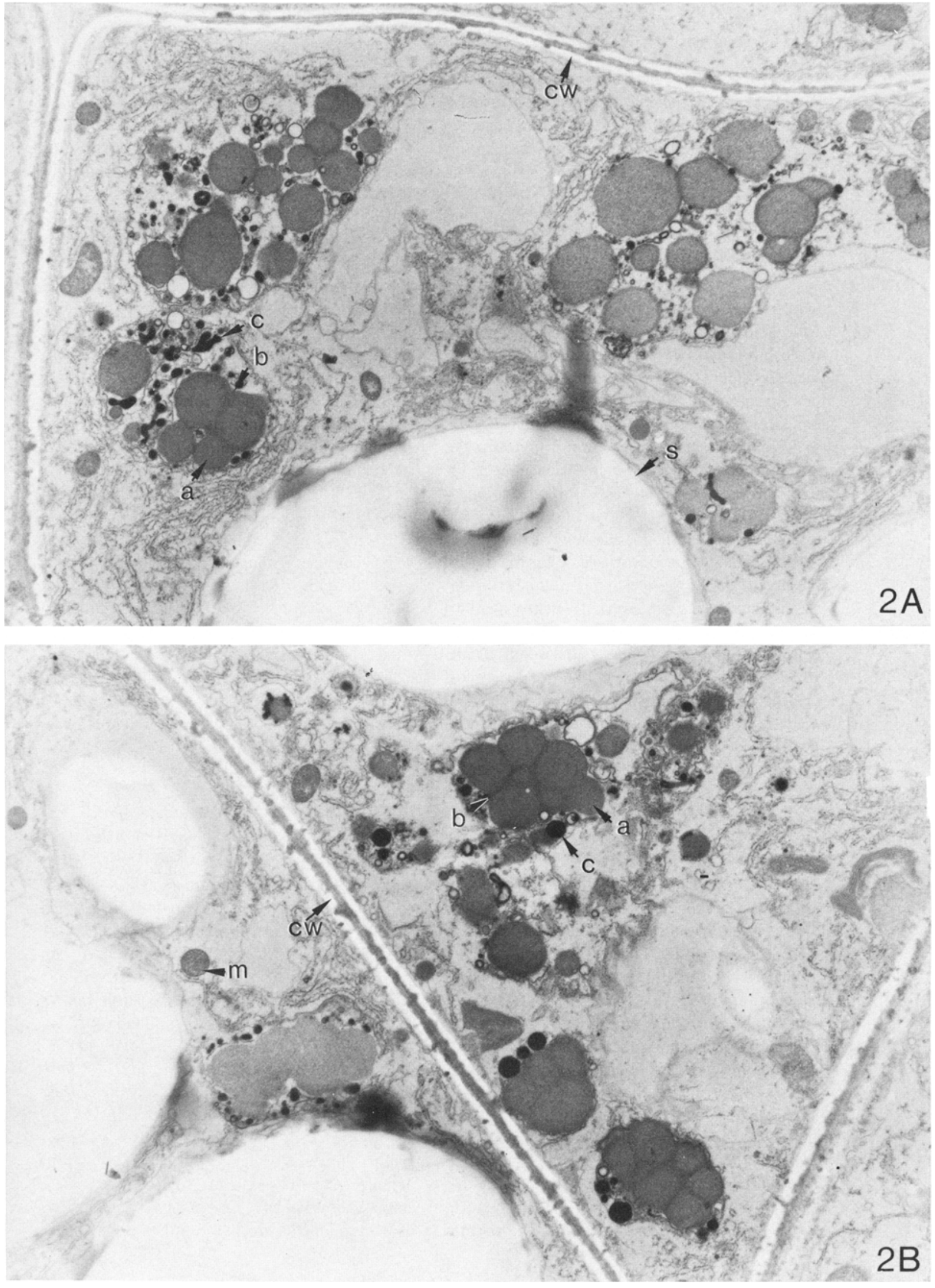



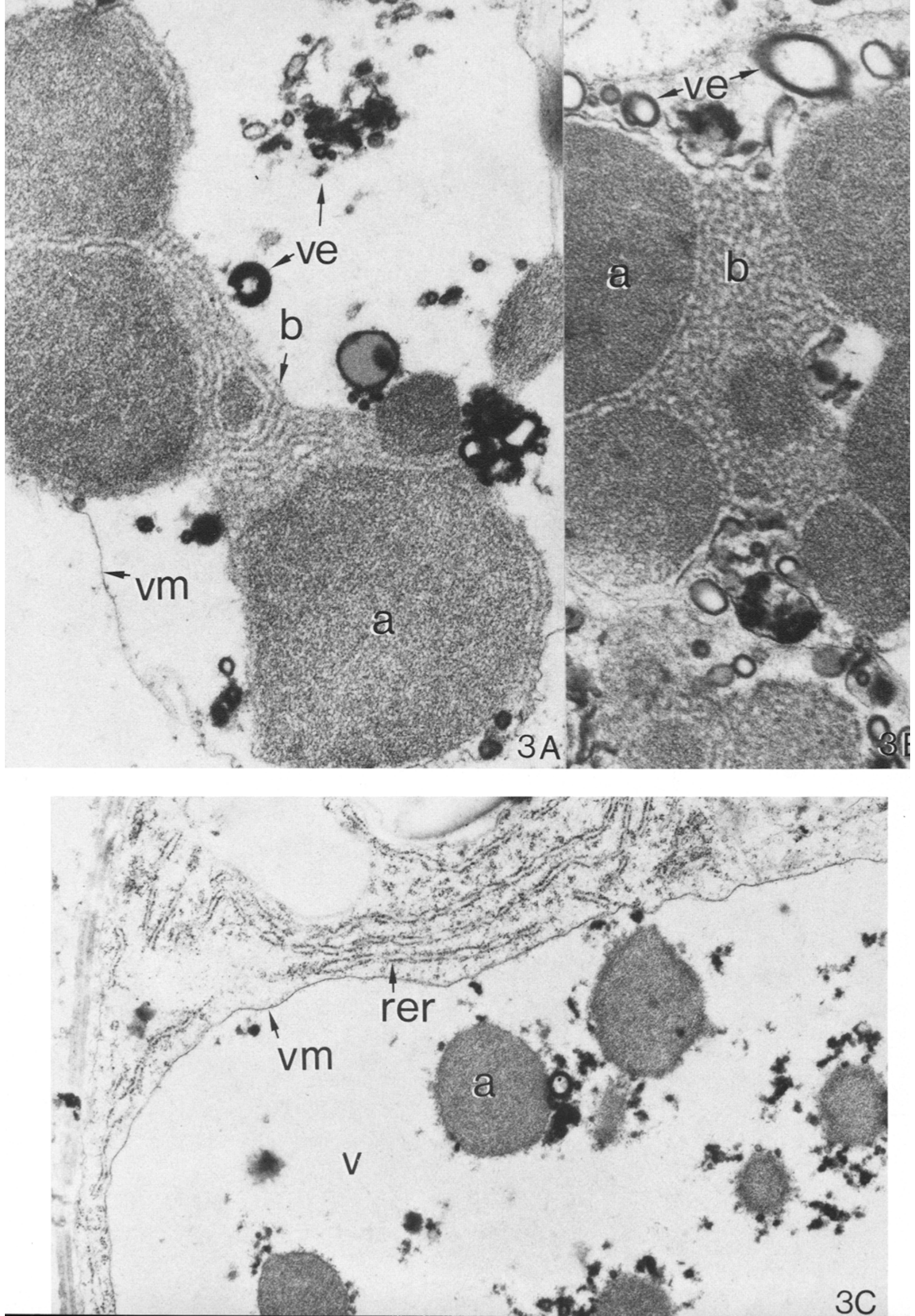


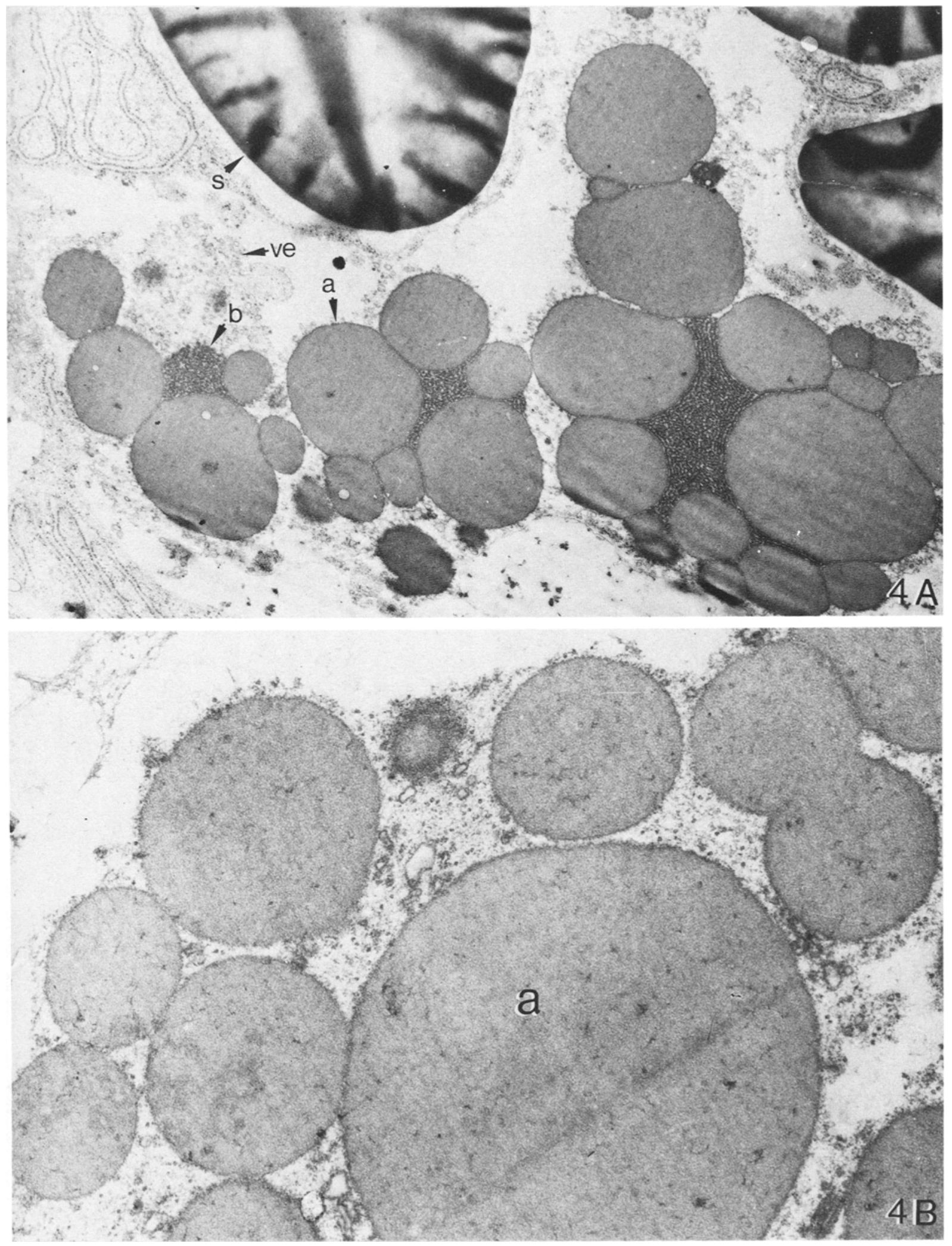



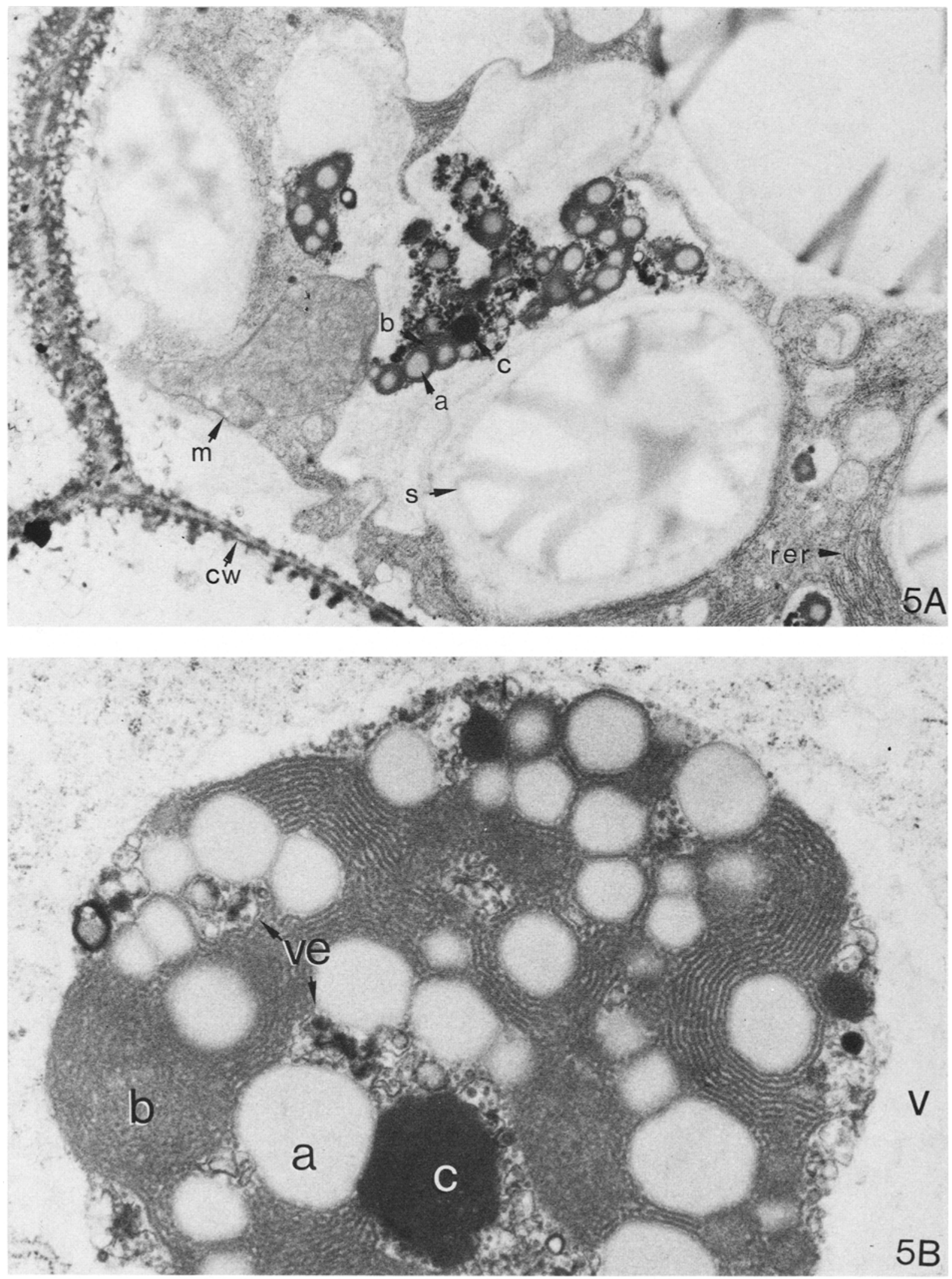


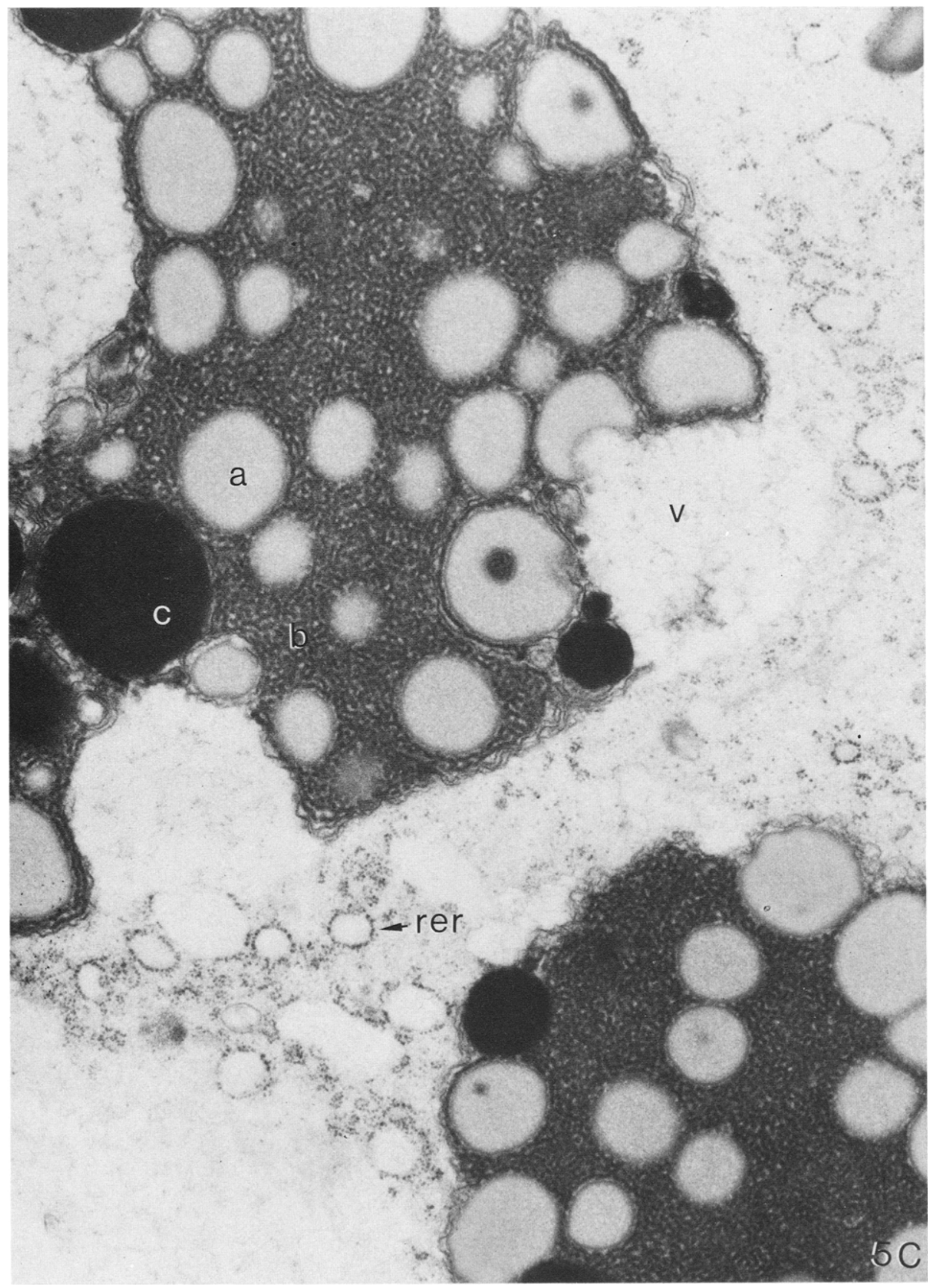




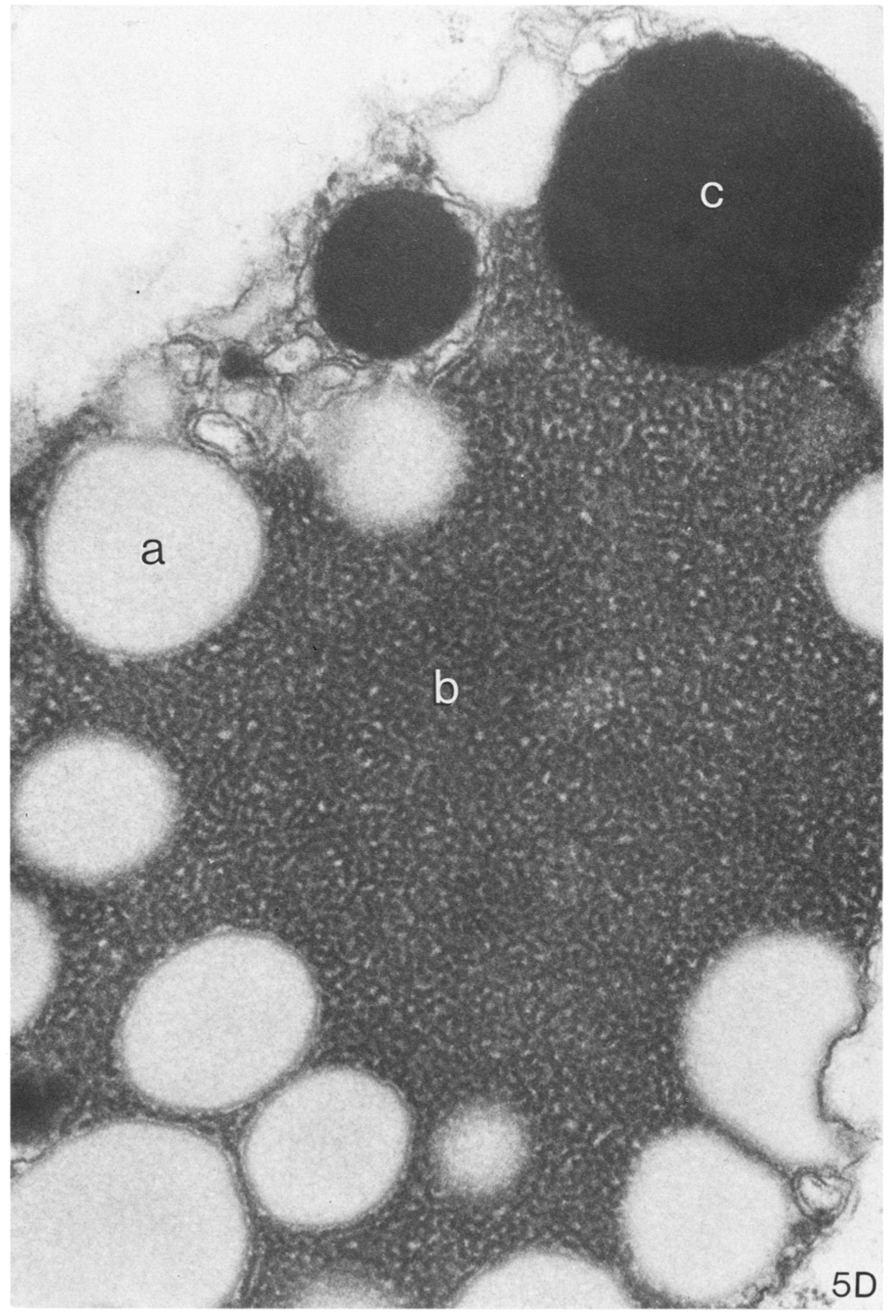




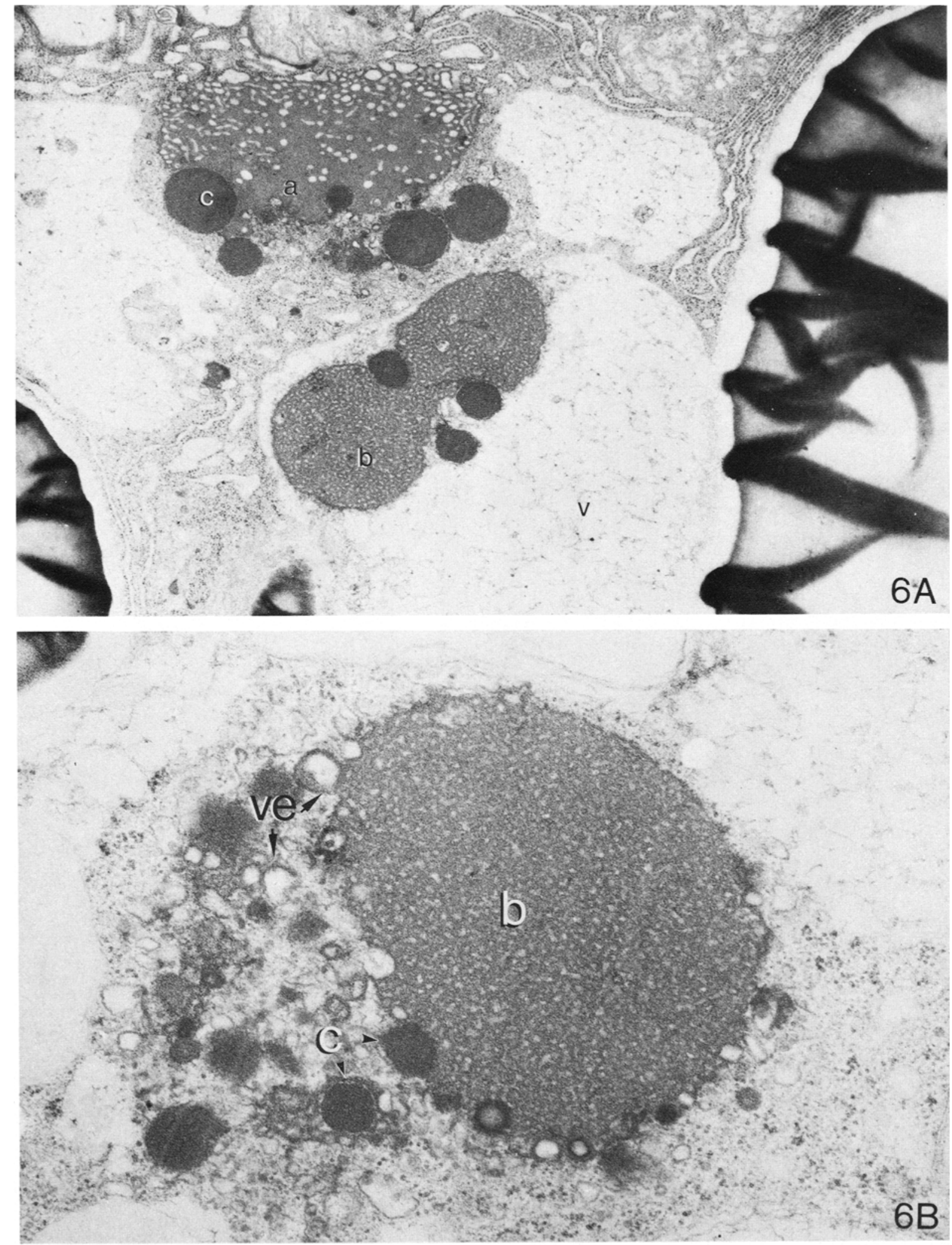




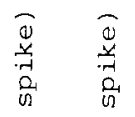

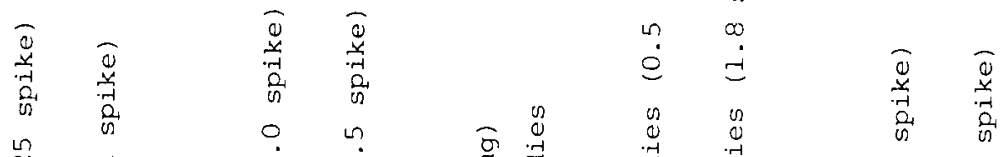

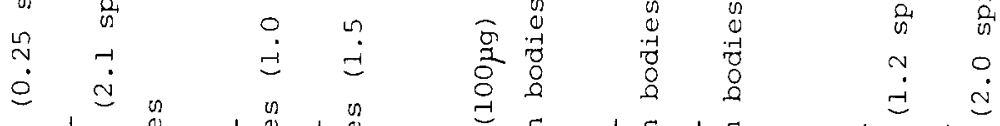

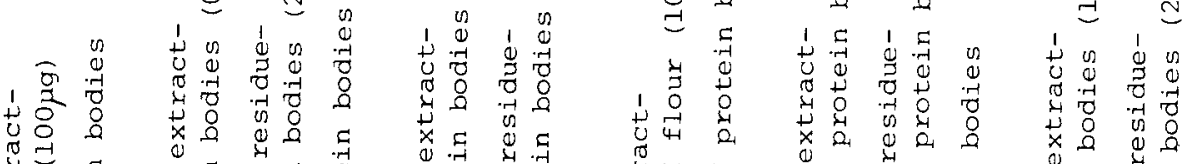

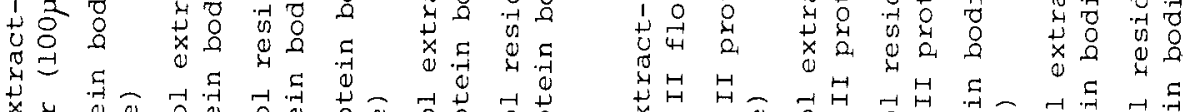

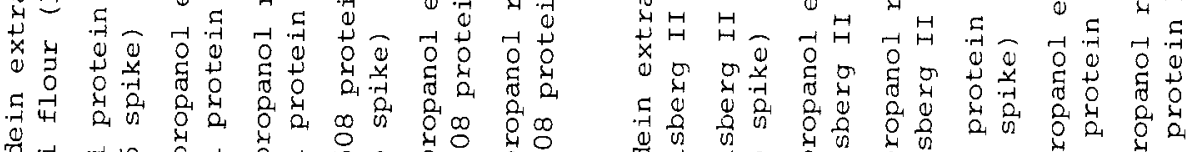

क्ष

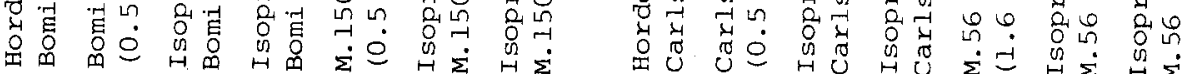

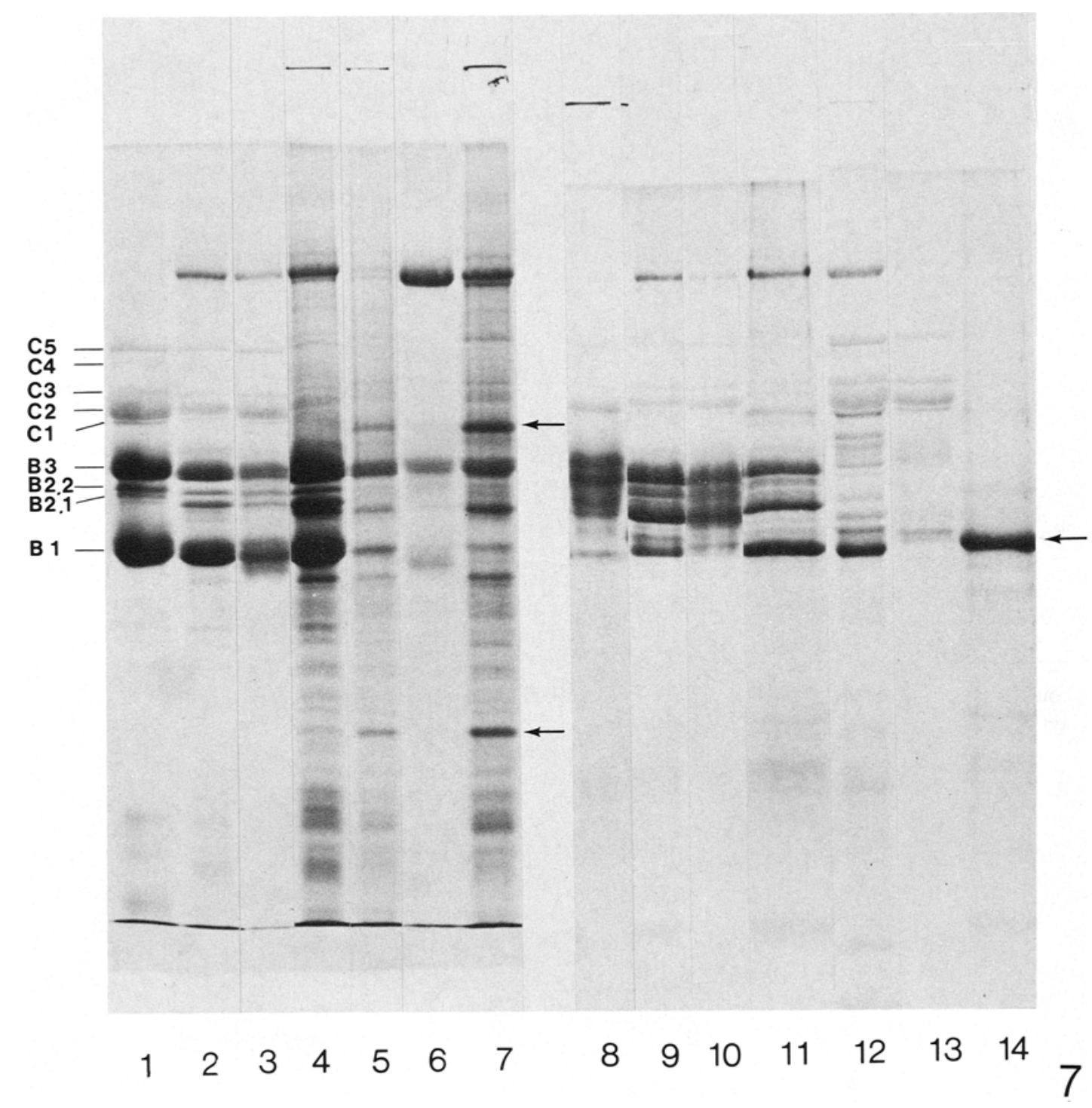




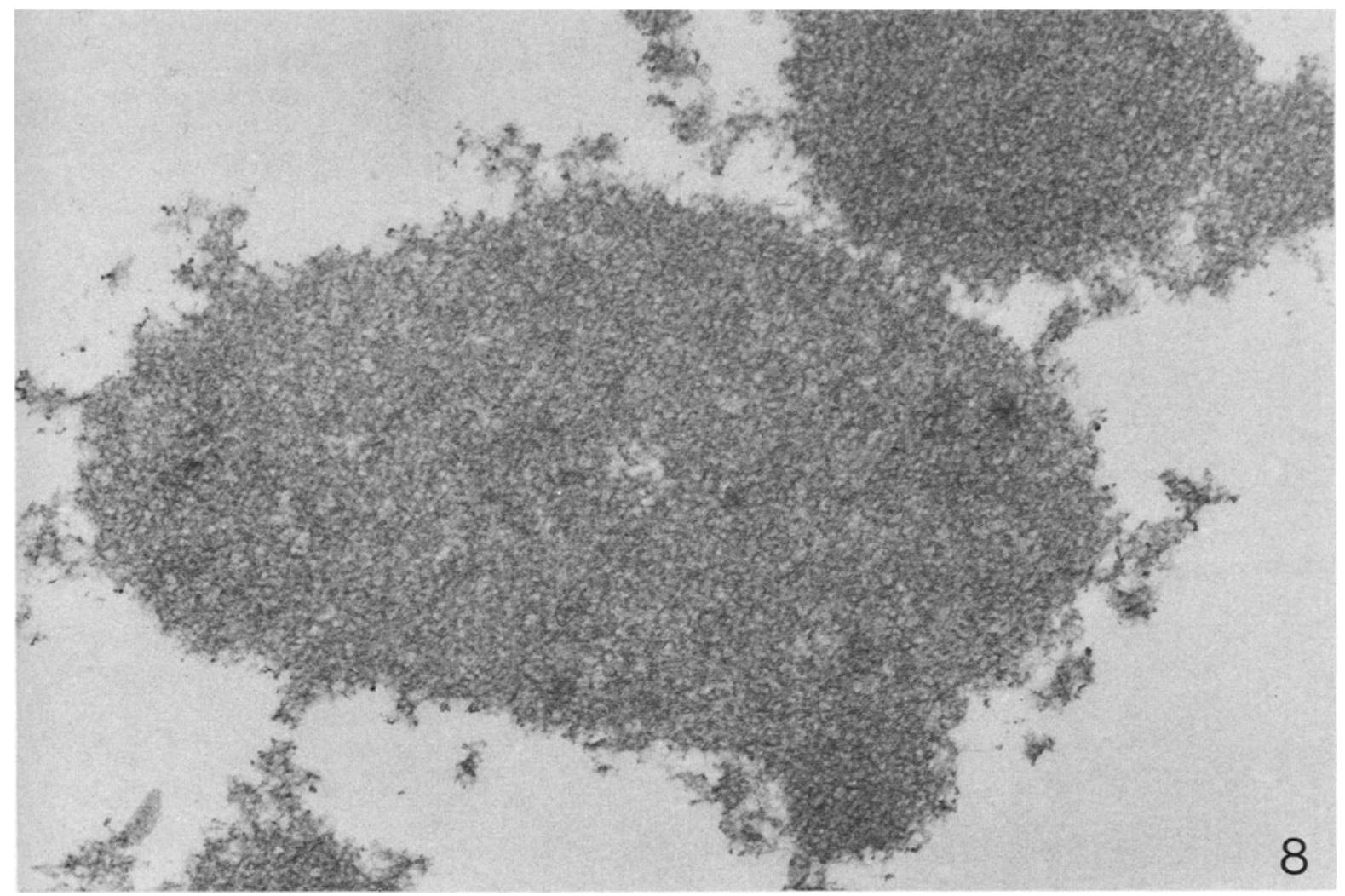

Figure 8. Electron micrograph of hordein extract of Bomi barley precipitated in $16 \%$ isopropanol.

Hordein polypeptides extracted from barley flour into $60 \%$ isopropanol, $2 \% \beta$-mercaptoethanol at $60^{\circ} \mathrm{C}$ were dialyzed repeatedly against $16 \%$ isopropanol. The precipitates formed were fixed in $2 \%$ glutaraldehyde dissolved in $16 \%$ isopropanol, postfixed with $\mathrm{OsO}_{4}$ and processed for thin sectioning as described in (7). Magnification: $\times 60,000$.

lying adjacent to the third layer of pyramidal cells in the section (Figure 2A, B). Here the vacuoles are packed with protein bodies and the rough endoplasmic reticulum in the surrounding cytoplasm is extensively proliferated. Dictyosomes are not common in the tissue. In addition to the fibrillar matrix, the clustered protein bodies are surrounded by many small electron-dense inclusions. Many appear to be uni- or multilamellar vesicles (Figure $3 \mathrm{~A}, \mathrm{~B}$ ) while others are dense spheres of less than $0.5 \mu$ in diameter.

The primary cell walls are traversed by numerous plasmodesmata and addition of the secondary walls is taking place as evidenced by the successive widening of the space between the plasmalemma and the primary wall.

\subsection{Ultrastructure of developing protein bodies}

Earlier descriptions of the ultrastructure of barley protein bodies have defined three components, namely the homogeneous deposits (component a) embedded in a fibrillar or granular matrix (component $b$ ) and frequently associated with electron-dense spheres (component c) (31, 42). Protein bodies from two barley lines have been examined in order to determine their ultrastructure. An additional insight into protein body formation has been gained from the two mutant barley lines where a reduced and modified synthesis of storage protein is associated with an altered protein body structure.

The individual homogeneous components (a) dispersed through large cell vacuoles in Carls- 
berg II barley endosperm have a fine granular structure (Figures 1 and 3C). The fibrillar component (b), which is restricted to the periphery of clustered homogeneous bodies, is seen in two sections cut parallel (Figure $3 \mathrm{~A}$ ) and perpendicular (Figure 3B) to the major direction of the fibrils. These are arranged in organised rows around the homogeneous components, and from their staining properties the two components appear to have a similar composition. The characteristic structure of developing protein bodies is thought to reflect the progressive dehydration and condensation of storage protein to yield the predominantly homogeneous structures seen in older seeds (Figure 4B). The fibrillar matrix may thus successively condense into the homogeneous components. The transient accumulation of the fibrillar component at sites of prolific storage protein deposition would be compatible with this hypothesis.

Protein bodies seen in the endosperm of Bomi barley, 20 days after anthesis, are very similar to those of Carlsberg II. The clusters of homogeneous deposits, interspersed with fibrillar component, are seen in vacuoles packed between the growing starch grains (Figure 4A). Numerous vesicles are seen adhering to the surface of the protein bodies and distributed through the vacuole. The electron-dense spheres seen in association with Carlsberg II protein bodies, are less frequent in Bomi endosperm.

In mutant 56, derived from Carlsberg II, the hordein content is reduced from $60 \%$ to $45 \%$ of total seed $N(37)$, but protein bodies can be found in the endosperm 19 days after anthesis. Comparing this mutant with the wild-type, it is immediately apparent that protein body formation is markedly altered. (Figure $5 \mathrm{~A}, \mathrm{~B}, \mathrm{C}, \mathrm{D}$ ). While the three component structure of the wildtype protein bodies can be discerned, the proportion of fibrillar matrix to homogeneous component is considerably increased. The clustered homogeneous deposits are less than half the diameter of those in the wild-type and the number of rows of surrounding fibrils is greatly increased. Unlike the wild-type, even the isolated homogeneous deposits are enclosed within fibrillar layers. The ordered structure of the fibrillar component filling the vacuole, surrounded by cytoplasm filled with rough endoplasmic reticulum, is seen in Figures $5 \mathrm{C}$ and D.
Electron-dense spheres are present in mutant 56 protein bodies, both at the periphery and embedded within the fibrillar matrix. Membrane vesicles commonly associated with protein bodies are also found embedded within the protein body clusters (Figure 5B).

The greatest depression in hordein synthesis among the various mutants examined has been recorded for the mutant 1508 derived from Bomi barley. This is accompanied by an altered protein body structure which is observable in endosperms 24 days after anthesis (Figure 6A). A failure of the storage proteins to condense into a homogeneous structure is indicated by the large channels which permeate even the more compacted protein bodies. At higher magnification the tightly packed fibrillar sub-structure is discernable throughout the protein body of the mutant (Figure 6B). The electron-dense spheres of component $\mathrm{c}$ are more common and larger than in the wild-type, while the accumulation of membrane vesicles in the vacuoles is similarly observed.

\subsection{Composition of developing protein bodies in relation to their ultrastructure}

The isolation and purification of protein bodies from these four barley lines has made it possible to examine their polypeptide composition (7). The barley storage protein hordein is the major component of isolated protein bodies (Figure 7 , tracks 2, 5, 9, 12). Hordein is comprised of at least 10 polypeptides and these can be solubilized and specifically extracted in $60 \%$ isopropanol, $2 \% \beta$-mercaptoethanol at $60^{\circ} \mathrm{C}$ (39) (Figure 7, tracks 3, 6, 10, 13). In addition to hordein, a number of polypeptides have been identified in the isopropanol-insoluble residue which are specific components of the protein bodies from each barley genotype. These polypeptides are indicated by an arrow in Figure 7 , tracks $7,11,14$

The hordein polypeptides can be divided into two major groups which differ in their apparent molecular weight, charge and amino acid composition (38). The structural genes for these two highly polymorphic groups of ' $B$ ' and ' $C$ ' polypeptides are located in two complex linked loci Hor-2 and Hor-1, respectively, which are located on the short arm of chromosome 5 (12). 
The amino acid composition of the separated 'B' and 'C' polypeptide groups and some of their individual members has been determined (36, 37). The ' $C$ ' group polypeptides are generally more hydrophobic, having a higher content of the hydrophobic amino acids glutamate/glutamine and proline and fewer of the essential amino acids than the 'B' group.

The hordein composition of Carlsberg II and Bomi barley is closely related, the ' $C$ ' hordein polypeptides having identical mobilities in SDSPAGE (Figure 7, tracks 2, 9). No significant differences could be discerned between the structure of developing protein bodies from these two barley varieties. Hordein synthesis in mutant 1508 is reduced to two 'B' hordein polypeptides and a single ' $\mathrm{C}$ ' hordein of which only the ' $\mathrm{B}$ ' group can be clearly distinguished in isolated protein bodies (Figure 7 , track 6 ). The absence of the more hydrophobic ' $\mathrm{C}$ ' hordein polypeptides and the reduction in ' $\mathrm{B}$ ' hordein polypeptides is associated with a failure of the deposited storage proteins to condense fully into a homogeneous structure.

A marked reduction of ' $\mathrm{B}$ ' hordein polypeptide synthesis is the main feature of mutant 56 endosperms, and the ' $\mathrm{C}$ ' hordein polypeptides are the major components of their protein bodies (Figure 7, track 13). This change in the proportion of 'B' to ' $\mathrm{C}$ ' hordein polypeptide synthesis is also associated with abnormal storage protein condensation and a marked accumulation of the fibrillar component.

\subsection{The deposition of storage protein in developing barley endosperms}

It has been demonstrated in vitro that the rough endoplasmic reticulum is the site of storage protein synthesis in the seeds of maize (5, $26,27)$, barley (9) and a number of legumes (2, 14,35 ). The newly synthesized polypeptides are thought to be released into the lumen of the rough endoplasmic reticulum, as observed in vitro, and then transported to their final site of deposition. In maize, the storage protein zein has been reported to accumulate within the lumen of the rough endoplasmic reticulum, and membrane-bound protein bodies can be isolated to which numerous polyribosomes are still attached $(5,22,26)$. However, in most seeds storage proteins are first seen in electron micrographs when they accumulate within smaller or larger vacuoles of the storage tissue $(1,6,11,15,18$, $30,31,32,34,42,43)$. The accumulation of storage protein in vacuoles has been questioned in the case of barley (28). Instead it is postulated that protein bodies are formed inside the endoplasmic reticulum and subsequently released into the cytoplasm. However, tonoplasts can be discerned around the supposedly free protein bodies in the cytoplasm in the published micrograph of Figure 13 in (28). Some storage proteins, such as the globulins in Phaseolus vulgaris, are glycosylated and the involvement of dictyosomes in their glycosylation and initial packaging is implicated (40).

The route whereby storage proteins are transported from the rough endoplasmic reticulum to the vacuole has yet to be determined by biochemical analyses in any plant seed. The vacuoles of barley ( 42 and this paper), wheat ( 30 , 34 ) and rice (29) endosperm contain many small vesicles aggregated around the protein bodies. It is conceivable that such smooth vesicles transport and discharge storage proteins into the vacuoles. In wheat endosperm, storage proteins are thought to be transported to the vacuole in dictyosome vesicles, which then accumulate within the vacuole to form various lipid-rich inclusions associated with the protein bodies (34). Whether the electron-dense spheres (component c) found in barley protein bodies include material derived from membrane vesicles accumulated within the vacuoles has yet to be studied.

During the development of the cotyledons of leguminous seeds the initial large vacuole is partitioned into smaller vacuoles, while deposition of storage protein on the inner surface of the vacuoles proceeds $(11,15,32,43)$. At later stages massive accumulation of storage protein occurs in the partitioned vacuoles and in smooth vesicles. The latter can be continuous with smooth portions of the endoplasmic reticulum filled with material of the same electron density $(11,32)$. An analogous differentiation of the endoplasmic reticulum has also been observed in barley (cf. 42) and will be described in a subsequent paper.

The formation of homogeneous deposits of storage protein seen in the endosperms of wheat, 
rice and barley may all depend on the progressive deposition and condensation of protein. A series of concentric layers has been observed at the periphery of developing rice (29) and wheat (18, 30) protein bodies and these, like the fibrillar matrix in barley, may represent an early stage in storage protein condensation.

Hordein polypeptides are extremely hydrophobic proteins, but precipitation of the newly synthesized polypeptides may be delayed to facilitate their transport from the endoplasmic reticulum to their final site of deposition in the vacuole. The solubility of these polypeptides in the endoplasmic reticulum cisternae and in hypothetical transport vesicles could be maintained by low protein concentrations or extremes of $\mathrm{pH}$ within the cisternae. Hordein is extracted from barley grain in $60 \%$ isopropanol, $2 \% \beta$ mercaptoethanol at $60^{\circ} \mathrm{C}$, but will precipitate at low temperatures or reduced isopropanol concentration. Electron microscopy of hordein extracts from Bomi barley, precipitated in 16\% aqueous isopropanol (Figure 8), reveals the spontaneous formation of protein body-like structures. The in vitro precipitation of hordein may closely resemble the first protein body deposits in the vacuole (Figure 3). The properties of the storage proteins are such that they will naturally associate and condense into tightly packed structures.

In conclusion, it has been demonstrated that the morphology of developing protein bodies is an expression of their polypeptide composition. Although the proportion of the different hordein polypeptides influences their precipitation pattern in developing protein bodies, even a large reduction in their total amount does not completely prevent the formation of these structures. Further studies will reveal to what extent eliminated hordein polypeptides can be substituted with polypeptides of nutritionally improved amino acid composition.

\section{ACKNOWLEDGEMENTS}

The assistance of ULLA EdÉn and JEAN SAGE in preparation of the electron micrographs is gratefully acknowledged. Verena CameronMills has been supported by a Wellcome Travelling Research Fellowship (1978/79) and the Carlsberg Laboratory (1979/80).

\section{REFERENCES}

1. Barlow, K. K., J. W. Lee \& M. VesK: Morphological development of storage protein bodies in wheat. In: Mechanisms of regulation of plant growth. R. L. Bieleski, A. R. Fergusen and M. M. Cresswell, eds. Bull. 12, The Royal Soc. of New Zealand, Wellington 1974. pp. 793-797 (1974)

2. Bollini, R. \& M. J. Chrispeels: The rough endoplasmic reticulum is the site of reserveprotein synthesis in developing Phaseolus vulgaris cotyledons. Planta 146, 487-501 (1979)

3. Bradbury, D., M. M. MacMasters \& I. M. Cull: Structure of mature wheat kernel. II. Microscopic structure of pericarp, seed coat, and other coverings of the endosperm and germ of hard red winter wheat. Cereal Chemistry 33, 342-360 (1956)

4. BRiggs, D. E.: Barley. Chapman and Hall, London (1978)

5. Burr, B., F. A. Burr, I. Rubenstein \& M. N. SIMON: Purification and translation of zein messenger RNA from maize endosperm protein bodies. Proc. Nat. Acad. Sci. USA, 696-708 (1978)

6. ButrRose, M. S.: Ultrastructure of the developing wheat endosperm. Aust. J. Biol. Sci. 16, 305-317 (1963)

7. Cameron-Milis, V.: The structure and composition of protein bodies purified from barley endosperm by silica sol density gradients. Carlsberg Res. Commun. 45, 557-576 (1980)

8. Cameron-Mills, V., A. Brandt \& J. Ingversen: The molecular biology of barley storage protein synthesis. In: Cereals for Food and Beverages. Eds. G. E. Inglett \& L. Munck. Acad. Press (1980)

9. Cameron-Mills, V. \& J. Ingversen: In vitro synthesis and transport of barley endosperm proteins: Reconstitution of functional rough microsomes from polyribosomes and stripped microsomes. Carlsberg Res. Commun. 43, 471489 (1978)

10. Cochrane, M. P. \& C. M. Duffus: Morphology and ultrastructure of immature cereal grains in relation to transport. Ann. Bot. 44, 67-72 (1979)

11. Craig, S., D. J. Goodchild \& A. R. Hardham: Structural aspects of protein accumulation in developing pea cotyledons. I. Qualitative and quantitative changes in parenchyma cell vacuoles. Aust. J. Pl. Physiol. 6, 81-98 (1979)

12. DolL, H. \& A. H. D. Brown: Hordein variation in wild (Hordeum spontaneum) and cultivated (H. vulgare) barley. Can. J. Genet. Cytol. 21, $391-404$ (1979) 
13. Duffus, C. M. \& R. Rosie: Some enzyme activities associated with the chlorophyll containing layers of the immature barley pericarp. Planta 114, 219-226 (1973)

14. Evans, I. M., R. R. D. Croy, P. Hutchinson, D. Boulter, P. I. PAYNe \& M. E. Gordon: Cell free synthesis of some storage protein subunits by polyribosomes and RNA isolated from developing seeds of pea (Pisum sativum L.). Planta 144, 455-462 (1979)

15. Harris, N. \& D. Boulter: Protein body formation in cotyledons of developing cowpea (Vigna unguiculata) seeds. Ann. Bot. 40, 739 744 (1976)

16. Jacobsen, J. V., R. B. Knox \& N. A. Pyliotis: The structure and composition of aleurone grains in the barley aleurone layer. Planta 101, 189209 (1971)

17. Jelsema, C. L., D. J. Morré, M. Ruddat \& C. TURNER: Isolation and characteristics of the lipid reserve bodies, spherosomes, from aleurone layers of wheat. Bot. Gaz. 138, 138-149 (1977)

18. Jennings, A. C., R. K. Morton \& B. A. Palk: Cytological studies of protein bodies of developing wheat endosperm. Aust. J. Biol. Sci. 16, 366-383 (1963)

19. JonASSEN, I.: Characteristics of Hiproly barley I. Isolation and characterization of two watersoluble high-lysine proteins. Carlsberg Res. Commun. 45, 47-58 (1980)

20. JoNASSEN, 1.: Characteristics of Hiproly barley II. Quantification of two proteins contributing to its high-lysine content. Carlsberg Res. Commun. 45, 59-68 (1980)

21. JoNEs, R. L.: The fine structure of barley aleurone cells. Planta 85, 359-375 (1969)

22. Kноо, U. \& M. J. WoLF: Origin and development of protein granules in maize endosperm. Am. J. Bot. 57, 1042-1050 (1970)

23. KREIS, M. \& H. Doll: Starch and prolamin level in single and double high-lysine barley mutants. Physiol. Plant 48, 139-143 (1980)

24. Kyle, D. J. \& E. D. Styles: Development of aleurone and sub-aleurone layers in maize. Planta 137, 185-193 (1977)

25. KøIE, B. \& H. Doll: Protein and carbohydrate components in the Risø high-lysine barley mutants. In: Seed Protein Improvement in Cereals and Grain Legumes, Vol. 1, IAEA, Vienna, pp. 205-215 (1979)

26. Larkins, B. A. \& W. J. Hurkman: Synthesis and deposition of zein in protein bodies of maize endosperm. Plant Physiol. 62, 256-263 (1978)

27. Larkins, B. A., K. Pedersen, A. K. Handa, W. J. Hurkman \& L. D. Smith: Synthesis and processing of maize storage proteins in Xenopus laevis oocytes. Proc. Nat. Acad. Sci. USA 76, 6448-6452 (1979)

28. Mifuin, B. J. \& P. R. Shewry: The synthesis of proteins in normal and high lysine barley seeds. In: Recent Advances in the Biochemistry of Cereals. Eds. D. L. Laidman \& R. G. Wyn Jones. Acad. Press (1979)

29. Mitsuda, H., K. Murakami, T. Kusano \& K. YaSUMOTO: Fine structure of protein bodies isolated from rice endosperm. Arch. Biochem. Biophys. 130, 678-680 (1969)

30. Morton, R. K., B. A. Palk \& J. K. Raison: Intracellular components associated with protein synthesis in developing wheat endosperm. Biochem. J. 91, 522-528 (1964)

31. Munck, L. \& D. von Wettstein: Effects of genes that change the amino acid composition of barley endosperm. In: Genetic Improvement of Seed Proteins. Proc. of a workshop 18-20 March, 1974. Nat. Acad. Sci. USA, pp. 71-82 (1976)

32. Neumann, D. \& E. Weber: Formation of protein bodies in ripening seeds of Vicia faba $\mathrm{L}$. Biochem. Physiol. Pflanzen. 173, 167-180 (1978)

33. Nutbeam, A. R. \& C. M. Duffus: Evidence for $\mathrm{C}_{4}$ photosynthesis in barley pericarp tissue. Biochem. Biophys. Res. Commun. 70, 11981203 (1976)

34. PARKer, M. L.: Protein body inclusions in developing wheat endosperm. Ann. Bot. 46, 2936 (1980)

35. Püchel, M., K. Müntz, B. Parthier, O. AuRich, R. Bassüner, R. Manteuffel \& $P$. ScHmidT: RNA metabolism and membranebound polysomes in relation to globulin biosynthesis in cotyledons of developing field bean. Eur. J. Biochem. 96, 321-338 (1979)

36. Sснмiтt, J. M.: Purification of hordein polypeptides by column chromatography using volatile solvents. Carlsberg Res. Commun. 44, 431-438 (1979)

37. Shewry, P. R., A. J. Faulks \& B. J. Mifuin: Effect of high-lysine mutations on the protein fractions of barley grain. Biochemical Genetics 18, 133-151 (1980)

38. Shewry, P. R., J. M. Field, M. A. Kirkman, A. J. FaulKS \& B. J. Mifun: The extraction, solubility, and characterisation of two groups of barley storage polypeptides. J. Exp. Bot. 31, 393-407 (1980)

39. Shewry, P. R., J. M. Hill, H. M. Pratt, M. M. LegGatT \& B. J. MifLin: An evaluation of techniques for the extraction of hordein and glutelin from barley seed and a comparison of 
the protein composition of Bomi and Rise 1508.

J. Exp. Bot. 29, 677-692 (1978)

40. SUn, S. M., Y. MA, B. U. Buchinder \& T. C. HaLL: Comparison of Gl polypeptides synthesized in vitro and in vivo in the presence and absence of a glycosylation inhibitor. Plant Physiol. Abstr. 62, 94 (1979)

41. Svendsen, J., B. Martin \& I. Jonassen: Characteristics of Hiproly barley III. Amino acid sequences of two lysine-rich proteins. Carlsberg Res. Commun. 45, 79-86 (1980)
42. WetTStein, D. von: Biochemical and molecular genetics in the improvement of malting barley and brewers yeast. Proc. 17th Eur. Brewery Convention Congr. Berlin 1979, pp. 588-629 (1979)

43. Yoo, B. Y. \& M. J. Chrispeels: The origin of protein bodies in developing soybean cotyledons: a proposal. Protoplasma 103, 201-204 (1980) 


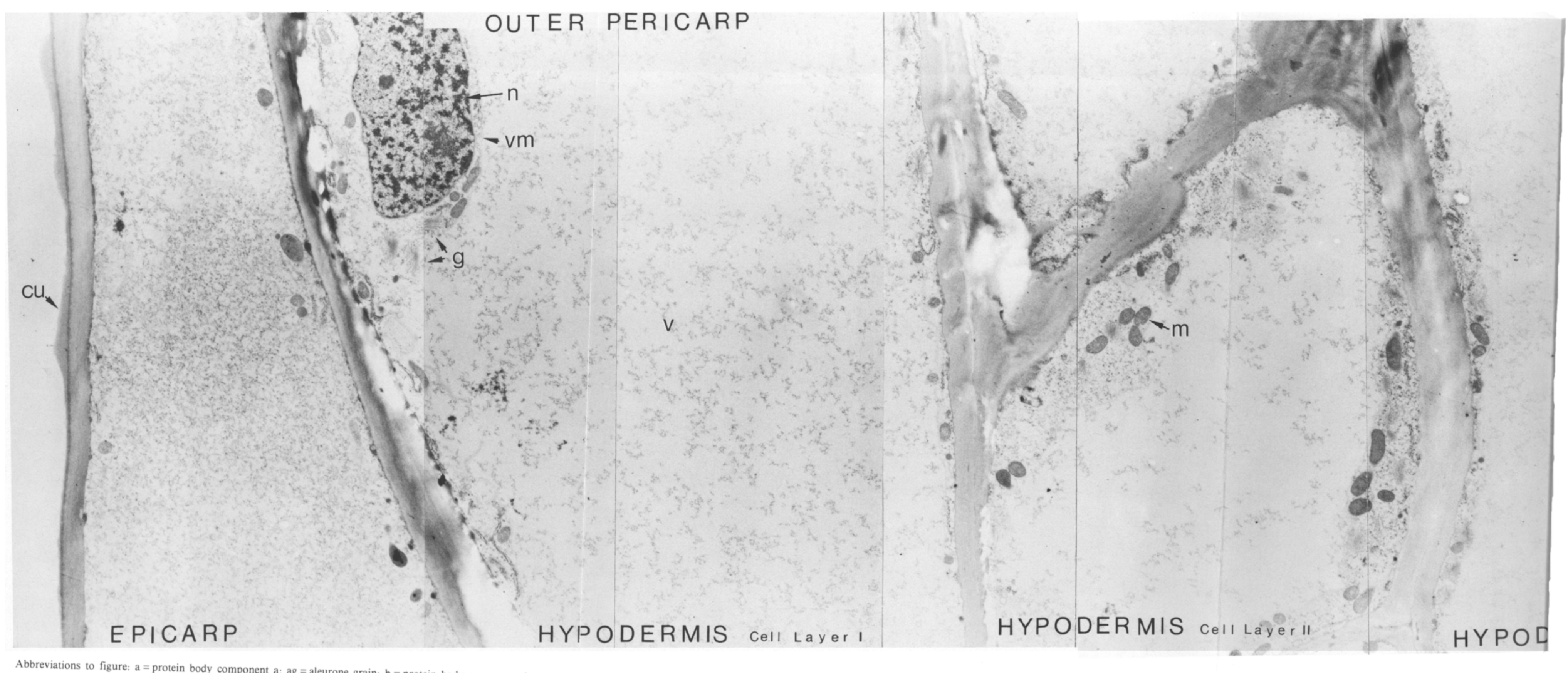

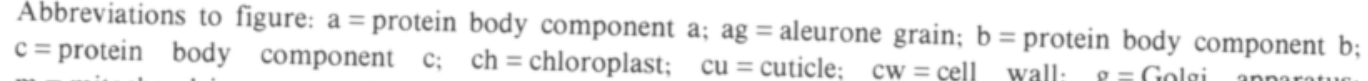
$\mathrm{c}=$ protein
$\mathrm{m}=$ mitochondrion;
$\mathrm{s}=\mathrm{n}=$ nucleus; $\quad \mathrm{o}=$ oleosome; $\mathrm{pb}=$ protein $\quad$ body; $\quad$ rer $=$ rough $\quad$ endoplasmic $\mathrm{s}=$ starch; $\mathrm{v}=$ vacuole; $\mathrm{ve}=$ vesicle; $\mathrm{vm}=$ vacuolar membrane. 


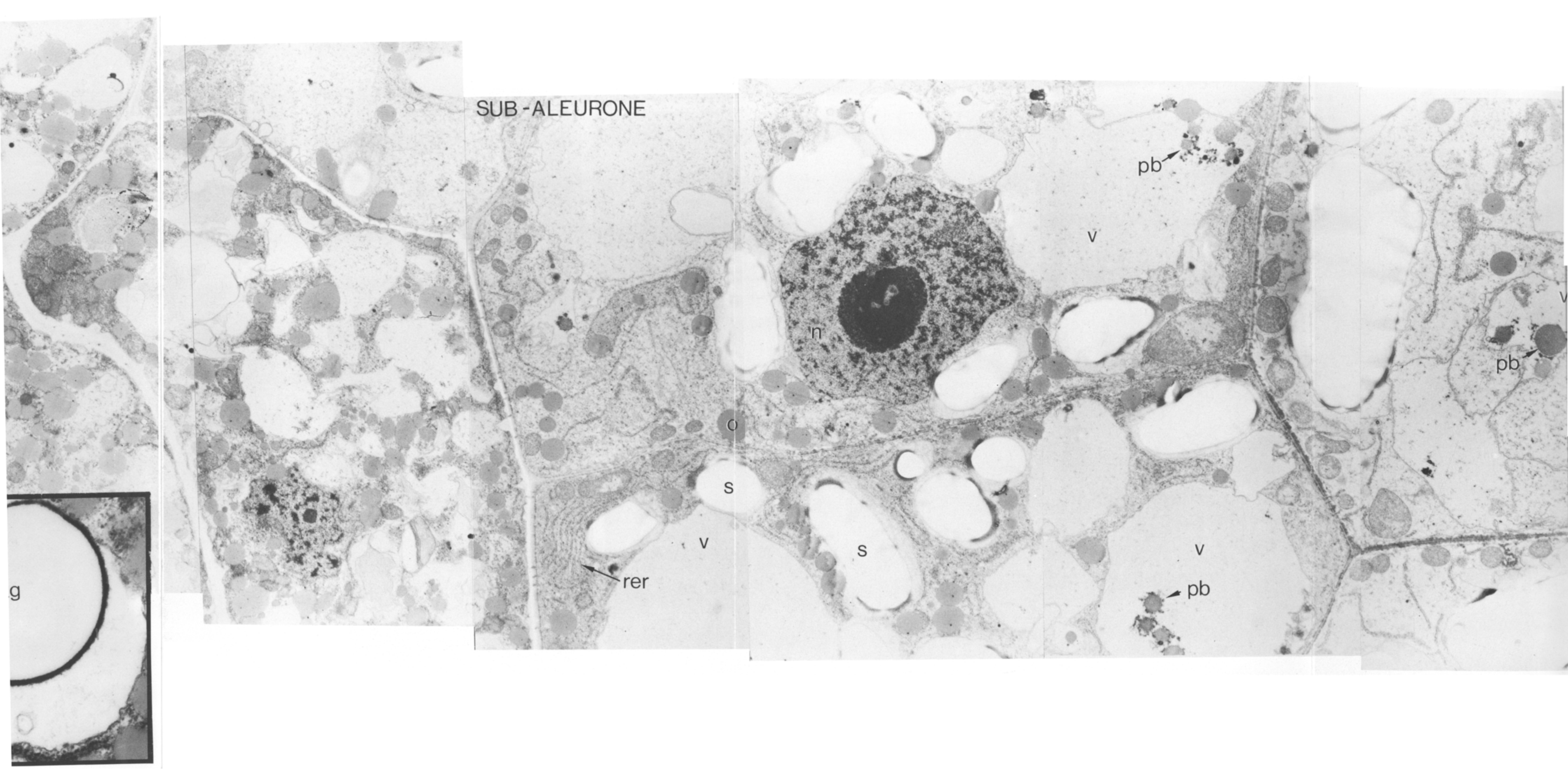




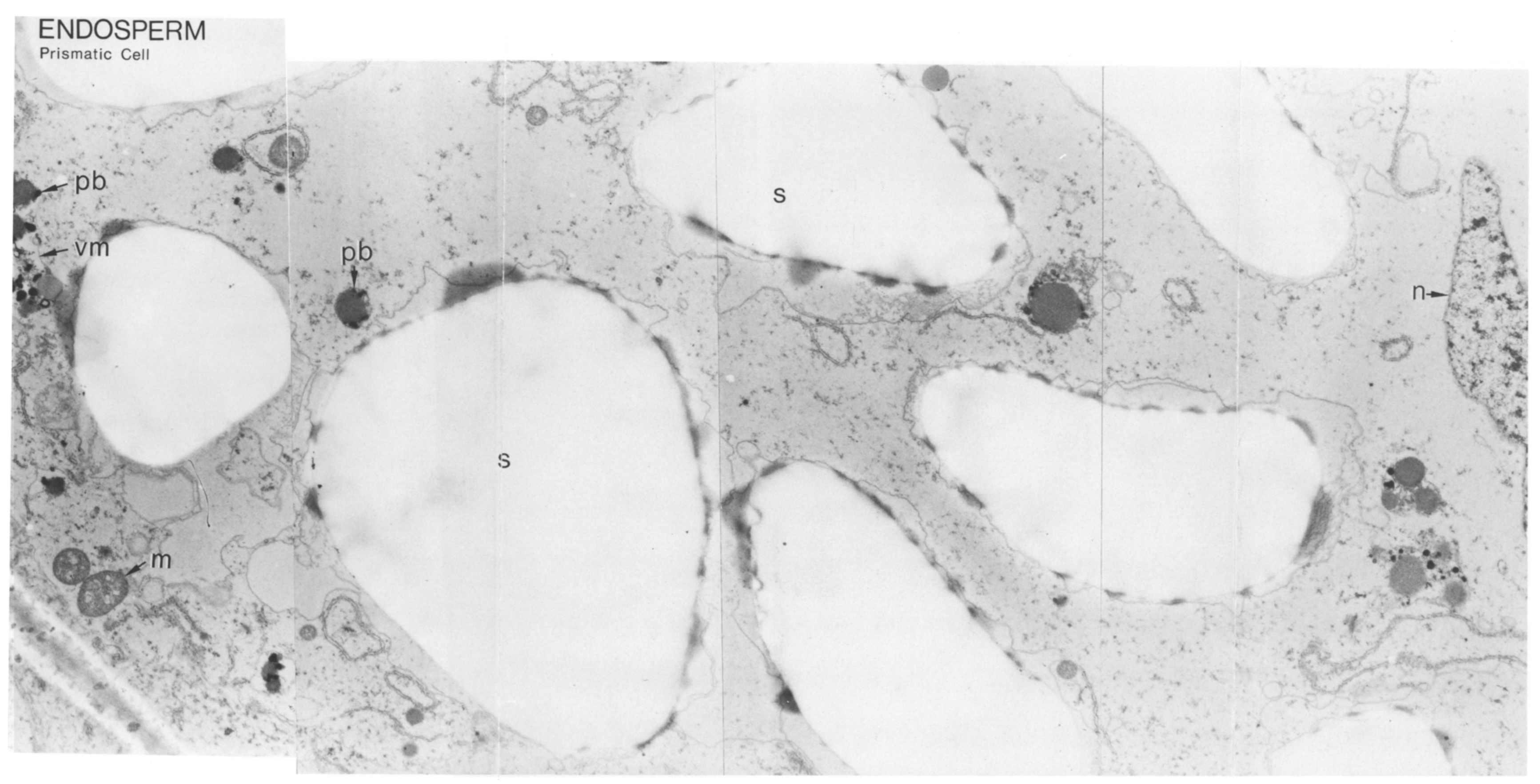

Abbreviations to figure: $\mathrm{a}=$ protein body component $\mathrm{a}$; $\mathrm{ag}=$ aleurone grain; $\mathrm{b}=$ protein body component $\mathrm{b}$ $\mathrm{c}=$ protein body component $\quad \mathrm{c} ; \quad \mathrm{ch}=$ chloroplast; $\quad \mathrm{cu}=$ cuticle; $\quad \mathrm{cw}=$ cell wall; $\mathrm{g}=$ Golgi apparatus;
$\mathrm{m}=$ mitochondrion; $\mathrm{n}=$ nucleus; $\mathrm{o}=$ = oleosome; $\mathrm{pb}=$ protein $\quad$ body; $\quad$ rer $=$ rough endoplasmic reticulum $\mathrm{s}=$ starch; $\mathrm{v}=$ vacuole; ve $=$ vesicle; $\mathrm{vm}=$ = vacuolar membrane.

Figure I. A section of a developing Carlsberg II barley grain (20 days after anthesis) cut tangential to the dorsal 